\title{
Effect of Costunolide and Dehydrocostus Lactone on Cell Cycle, Apoptosis, and ABC Transporter Expression in Human Soft Tissue Sarcoma Cells
}

Authors

Affiliations
Nadine Kretschmer ${ }^{1}$, Beate Rinner ${ }^{2}$, Nicole Stuendl ${ }^{3}$, Heike Kaltenegger ${ }^{3}$, Elisabeth Wolf ${ }^{3}$, Olaf Kunert ${ }^{4}$, Herbert Boechzelt ${ }^{5}$, Andreas Leithner ${ }^{3}$, Rudolf Bauer ${ }^{1}$, Birgit Lohberger ${ }^{3}$

The affiliations are listed at the end of the article
Key words

- Saussurea lappa

- Asteraceae

- dehydrocostus lactone

- soft tissue sarcoma

- cell cycle analysis

- ABCB1/MDR1

- $A B C G 2 / B C R P 1$

received February 21, 2012

revised August 13, 2012

accepted August 22, 2012

\section{Bibliography}

Dol http://dx.doi.org/ 10.1055/s-0032-1315385

Published online October 9 , 2012

Planta Med 2012; 78:

1749-1756 @ Georg Thieme

Verlag KG Stuttgart · New York .

ISSN 0032-0943

\section{Correspondence}

\section{Dr. Birgit Lohberger}

Department of Orthopaedic

Surgery

Medical University of Graz

Auenbruggerplatz 5

8036 Graz

Austria

Phone: + 4331638517630

Fax: +4331638514806

birgit.lohberger@

medunigraz.at

\section{Abstract}

$\nabla$

Human soft tissue sarcomas represent a rare group of malignant tumours that frequently exhibit chemotherapeutic resistance and increased metastatic potential following unsuccessful treatment. In this study, we investigated the effects of costunolide and dehydrocostus lactone, which have been isolated from Saussurea lappa using activity-guided isolation, on three soft tissue sarcoma cell lines of various origins. The effects on cell proliferation, cell cycle distribution, apoptosis induction, and $\mathrm{ABC}$ transporter expression were analysed.

Both compounds inhibited cell viability doseand time-dependently. $\mathrm{IC}_{50}$ values ranged from $6.2 \mu \mathrm{g} / \mathrm{mL}$ to $9.8 \mu \mathrm{g} / \mathrm{mL}$. Cells treated with costunolide showed no changes in cell cycle, little in caspase 3/7 activity, and low levels of cleaved caspase-3 after 24 and $48 \mathrm{~h}$. Dehydrocostus lactone caused a significant reduction of cells in the G1 phase and an increase of cells in the $\mathrm{S}$ and G2/M phase. Moreover, it led to enhanced caspase 3/7 activity, cleaved caspase-3, and cleaved PARP indicating apoptosis induction. In addition, the influence of costunolide and dehydrocostus lactone on the expression of ATP binding cassette trans-

\section{Introduction \\ $\nabla$}

STS represent a rare group of malignant tumours of various histologies which frequently exhibit aggressive characteristics both locally and in the formation of distant metastases [1]. The most important prognostic factors are the histological subtype and grade [2,3]. Frequently, STS exhibit chemotherapeutic resistance and increased metastatic potential. The efficacy of chemotherapy, which is currently one of the most effective ways to treat metastatic cancers, is limited [4-7]. Of the various mechanisms that are involved in confer- porters related to multidrug resistance (ABCB1/ MDR1, ABCC1/MRP1, and ABCG2/BCRP1) was examined using real-time RT-PCR. The expressions of ABCB1/MDR1 and ABCG2/BCRP1 in liposarcoma and synovial sarcoma cells were significantly downregulated by dehydrocostus lactone.

Our data demonstrate for the first time that dehydrocostus lactone affects cell viability, cell cycle distribution and $A B C$ transporter expression in soft tissue sarcoma cell lines. Furthermore, it led to caspase 3/7 activity as well as caspase-3 and PARP cleavage, which are indicators of apoptosis. Therefore, this compound may be a promising lead candidate for the development of therapeutic agents against drug-resistant tumours.

\section{Abbreviations \\ $\nabla$ \\ ABC transporter: ATP binding cassette transporter protein \\ STS: \\ SW-872: \\ SW-982: soft tissue sarcomas human liposarcoma cell line human synovial sarcoma cell line \\ TE-671: human rhabdomyosarcoma cell line}

ring resistance, upregulation of drug efflux transmembrane ABC transporters, such as P-glycoprotein (ABCB1/MDR1), multidrug resistance protein 1 (ABCC1/MRP1), and ABCG2/BCRP1, has become a major obstacle to cancer chemotherapy and seriously affects the clinical outcome [8-11]. $\mathrm{ABCB} 1$ is the best known drug transporter and seems to be induced in response to chemotherapeutic treatment. $A B C B 1$ expression was the highest in the largest and most aggressive tumours in a range of soft tissue sarcomas [12]. Inhibition of ABCG2 in tumour cells has been reported to increase the intracellular drug concen- 
tration and the efficacy of chemotherapeutics, whereas inhibition of ABCG2 in the liver and intestine may attenuate its defence against environmental toxicants [13]. The ABCC1 pump confers resistance to doxorubicin, daunorubicin, vincristine, colchicines, and several other compounds and has a very similar profile to ABCB1 [14]. Plants and their constituents have always played a central role in the search for new anticancer drugs. To date, about $73 \%$ of all approved anticancer drugs are either products derived from natural sources or developed based on knowledge won from natural products [15]. In a systematic bioactivity-based screening of plants used in traditional Chinese medicine, seventy-six plants were obtained in China and tested for their growth-inhibitory activity against tumour cells. Twenty-three of 253 extracts showed high activity [16]. One of these plants was Saussurea lappa Clarke (Asteraceae) which is traditionally used to treat asthma, cancer, cholera, rheumatism, chronic inflammations of the lung, indigestion, nausea, and vomiting $[17,18]$. Besides other terpenoid compounds [19,20], sesquiterpene lactones, including costunolide and dehydrocostus lactone, are the major components of the roots and have been reported to exhibit various biological activities [18,21,22]. Based on an improved knowledge of tumour biology, agents with novel and specific mechanisms of action may add to existing therapies for drug-resistant tumours.

In the present study, we investigated the effects of costunolide and dehydrocostus lactone on cell proliferation, cell cycle, apoptosis, and the expression of $\mathrm{ABC}$ transporters of three human soft tissue sarcoma cell lines of various origins.

\section{Material and Methods}

$\nabla$

\section{Plant material and extraction}

Roots of Saussurea lappa Clarke were acquired at the medicinal plant market in Kunming, China, in November of 2002 and identified by Prof. Dr. X.-J. Hao, Kunming Institute of Botany, Chinese Academy of Sciences, Kunming, China. A specimen copy (\#05301-01-0-00) is on deposit in the herbarium of the Institute for Plant Sciences, Karl-Franzens University Graz, Austria. Fifty-five g fresh powdered material was successively and exhaustively extracted with petroleum ether and $\mathrm{MeOH}$ by Soxhlet extraction and dried under reduced pressure at $40^{\circ} \mathrm{C}$. The yields were $1.7 \mathrm{~g}$ and $19.8 \mathrm{~g}$, respectively.

\section{Isolation procedure}

Costunolide and dehydrocostus lactone were isolated from the petroleum ether extract using preparative HPLC. Two hundred $\mathrm{mg}$ extract was dissolved in acetonitrile $(40 \mathrm{mg} / \mathrm{mL})$ and subjected to a preparative HPLC consisting of a Varian Prep Star pump (model SD-1) and a Dynamax absorbance detector model UV-1. Fractionation was performed with a VDSpher 100 RP18 column $(250 \times 25 \mathrm{~mm}, 10 \mu \mathrm{m})$. The mobile phase consisted of A: water and $\mathrm{B}$ : acetonitrile, and the following gradient was used: 0-10 min, $84 \%$ B; $10-15 \mathrm{~min}, 84-100 \%$ B. Flow rate was $20 \mathrm{~mL} /$ min. The collected fractions were dried under reduced pressure. Both compounds were identified using a Varian Unitylnova $400 \mathrm{MHz}$ (400 MHz for ${ }^{1} \mathrm{H}$ and $100 \mathrm{MHz}$ for ${ }^{13} \mathrm{C}$ ) spectrometer at $25^{\circ} \mathrm{C}$ using TMS as the internal standard. Both were measured in pyridine- $d_{5}$ (Sigma-Aldrich). The yield of costunolide was $39.5 \mathrm{mg}$. A second purification using the same parameters yielded $37.4 \mathrm{mg}$ dehydrocostus lactone.

\section{Sample preparation}

Extracts and isolated compounds were dissolved in DMSO and diluted with culture medium. The final DMSO concentration never exceeded $0.5 \%$ and did not affect the cells. Vehicle-treated cells served as a control.

\section{Cell culture}

SW-872, SW-982, and TE-671 cell lines were obtained from CLS. They were cultured in Dulbecco's modified Eagle's medium (DMEM-F12; $\mathrm{GIBCO}^{\circledR}$, Invitrogen), containing $5 \%$ foetal bovine serum (FBS; GIBCO ${ }^{\circledR}$, Invitrogen), $1 \%$ L-glutamine $\left(\mathrm{GIBCO}^{\circledR}\right.$, Invitrogen), 100 units/mL penicillin (GIBCO ${ }^{\circledR}$, Invitrogen), $100 \mu \mathrm{g} / \mathrm{mL}$ streptomycin $\left(\mathrm{GIBCO}^{\circledR}\right.$, Invitrogen), and $0.25 \mu \mathrm{g}$ amphotericin B (PAA Laboratory) at $37^{\circ} \mathrm{C}$ in a humidified atmosphere of $5 \% \mathrm{CO}_{2}$. The medium was replaced every 3 days, and cell passages were continued upon reaching confluence. CCRF-CEM leukaemia cells (provided by the German Cancer Research Center, Heidelberg, Germany) were grown in RPMI 1640 medium $\left(\right.$ GIBCO $^{\circledR}$, Invitrogen), $1 \%$ L-glutamine, $10 \% \mathrm{FBS}$, and $1 \%$ penicillin/streptomycin.

\section{Cell viability assay}

The CellTiter $96^{\circledR} \mathrm{AQ}_{\text {ueous }}$ Assay (Promega) is composed of solutions of a novel tetrazolium compound MTS (3-(4,5-dimethylthiazol-2-yl)-5-(3-carboxymethoxyphenyl)-2-(4-sulfophenyl)-2Htetrazolium) and an electron coupling reagent PMS (phenazine methosulfate). The quantity of the formazan product as measured by the absorbance at $490 \mathrm{~nm}$ is directly proportional to the number of living cells in the culture [23]. $1 \times 10^{4}$ cells $(100 \mu \mathrm{L})$ were seeded into 96-well microtitre plates (Brand), and the assay was performed following the manufacturers' instructions. The commercial chemotherapeutics cisplatin and doxorubicin were used as positive controls.

\section{Cell cycle analysis}

After incubation with the respective $\mathrm{IC}_{50}$ concentrations of costunolide or dehydrocostus lactone for 48 and $72 \mathrm{~h}$, cells were harvested by trypsinisation. Ice-cold ethanol (70\%) was used to fix $5 \times 10^{5}$ cells for $10 \mathrm{~min}$ at $4{ }^{\circ} \mathrm{C}$. After washing with PBS, the cell pellet was resuspended in propidium iodid (PI) staining buffer $(50 \mu \mathrm{L} / \mathrm{mL}$ PI, RNAse A; Beckman Coulter) and incubated for $15 \mathrm{~min}$ at $37^{\circ} \mathrm{C}$. Cell cycle distribution was analysed by a FACSCalibur (BD Biosciences) using ModFit software. To investigate cell proliferation, the proliferation index (Pi) and S-phase cell fraction (SPF) were calculated. Pi is expressed as $\mathrm{Pi}=\left(\mathrm{S}+\mathrm{G}_{2} / \mathrm{M}\right)$ / $\left(G_{0} / G_{1}+S+G_{2} / M\right)$. SPF is expressed as SPF $=S /\left(G_{0} / G_{1}+S+G_{2} / M\right)$.

\section{Annexin V-FITC/PI apoptosis assay}

The FITC annexin V apoptosis detection kit (BD Biosciences) was performed following the manufacturers' instructions. Apoptotic cells were identified by resuspending $1 \times 10^{5}$ cells in $100 \mu \mathrm{L}$ annexin $\mathrm{V}$ binding buffer containing $5 \mu \mathrm{L}$ annexin $\mathrm{V}$-FITC and $5 \mu \mathrm{L}$ PI for $15 \mathrm{~min}$ at room temperature. Flow cytometry analysis was performed with FACS Calibur (BD Biosciences). 10000 events were collected. Cells were identified in the side scatter and forward scatter with a linear scale. Fluorescence signals were shown with a logarithmic scale. Compensation was performed by single annexin and PI measurements and analysed by FCS3 express software (De Novo software). Untreated cells were used as a negative control. 


\section{Caspase-3 apoptosis assay}

After incubation with the respective $\mathrm{IC}_{50}$ concentrations of costunolide or dehydrocostus lactone for 24 and $48 \mathrm{~h}$, cells were harvested by trypsinisation, fixed with formaldehyde for $10 \mathrm{~min}$ at $37^{\circ} \mathrm{C}\left(2 \times 10^{6}\right.$ cells $\left./ \mathrm{mL}\right)$ and permeabilised with methanol. The pellet was resuspended in incubation buffer (PBS:FBS 1:200) and stained with FITC-conjugated monoclonal active caspase-3 antibody (Cell Signaling Technology). Cells were analysed by flow cytometry (FACSCalibur; BD Biosciences) performed with FACSDiva software. Histograms were created using FCS3 express software (De Novo software). Untreated cells were used as a negative control.

\section{Caspase-Glo ${ }^{\circledR} 3 / 7$ assay}

10000 cells/well $(100 \mu \mathrm{L})$ were treated with the respective $\mathrm{IC}_{50}$ concentrations of the compounds for 6-72 $\mathrm{h}$ and analysed regarding caspase activation using the Caspase-Glo ${ }^{\circledR} 3 / 7$ assay according to the manufacturer's protocol. Luminescence was measured 30 min after adding the Caspase-Glo ${ }^{\circledR} 3 / 7$ reagent (Caspase-Glo ${ }^{\circledR}$ substrate and buffer).

\section{Western blot analysis}

For total protein analysis, cells were resuspended in lysis buffer ( $50 \mathrm{mM}$ Tris-HCl pH 7.4, $150 \mathrm{mM} \mathrm{NaCl}, 50 \mathrm{mM} \mathrm{NaF}, 1 \mathrm{mM}$ EDTA, $10 \%$ NP- $40,1 \%$ Triton-X and protease inhibitors), incubated on ice for $10 \mathrm{~min}$ and centrifuged at $15000 \mathrm{rpm}$ for $15 \mathrm{~min}$. Aliquots of protein extracts $(20 \mu \mathrm{g})$ were separated on $12 \%$ SDS-PAGE and electroblotted onto a $0.45 \mu \mathrm{m}$ Hybond ECL nitrocellulose membrane (Amersham Biosciences). The membrane was blocked with $3 \%$ milk blocking buffer for $1 \mathrm{~h}$ and incubated with the primary antibodies for $2 \mathrm{~h}$ at room temperature. As primary antibodies, mouse polyclonal PARP antibody (\#9542; New England Biolabs), rabbit polyclonal ABCB1/MDR1 (\# sc-13131; Santa Cruz Biotechnology), and rabbit polyclonal ABCG2 (H-70) (\# sc-25821; Santa Cruz Biotechnology) were used. The blots were developed using horseradish peroxidase-conjugated secondary antibodies (Dako) at room temperature for $1 \mathrm{~h}$ and the SuperSignal ${ }^{\circledR}$ West Pico chemoluminescent substrate (Thermo Scientific), in accordance with the manufacturers' protocol.

\section{Real-time RT-PCR}

Real-time RT-PCR was performed to determine the relative expression of the $A B C$ transporter genes $A B C B 1 / M D R 1, A B C C 1 /$ MRP1, and ABCG2/BCRP1. Total RNA was isolated from treated and untreated cells with RNeasy Mini Kit (Qiagen), following the manufacturer's recommended protocol. DNA was digested with $1 \mathrm{U}$ DNase (Fermentas) per $\mu \mathrm{g}$ RNA. One $\mu \mathrm{g}$ RNA was reversetranscribed using RevertAid cDNA synthesis kit (Fermentas). Real-time PCR reactions were performed in triplicates using the Platinum SYBR Green Super Mix with ROX (Invitrogen) on AB7900HT (Applied Biosystems, Invitrogen). The housekeeping genes glyceraldehyde 3-phosphate dehydrogenase (GAPDH), $\beta$ actin (ACTB), and hypoxanthine phosphoribosyltransferase (hprt-n) served as an internal control due to their stable expression in different tissues. The following primers were used: ABCB1/MDR1 (multidrug resistance protein): forward GAGGAAGACATGACCAGGTA and reverse CTGTCGCATTATAGCATGAA; ABCC1/MRP1: forward AGTGGAACCCCTCTCTGTTTAAG and reverse CCTGATACGTCTTGGTCTTCATC; ABCG2/BCRP1 (breast cancer resistance protein): forward ACCTGAAGGCATTTACTGAA and reverse TCTTTCCTTGCAGCTAAGAC; GAPDH: forward AAGGTCGGAGTCAACGGA and reverse ACCAGAGTTAAAAGCAGCCCT; hprt- n: forward ATGGGAGGCCATCACATT and reverse ATGTAATCCAGCAGGTCAGCAA and ACTB: forward CTGGAACGGTGAAGGTGACA and reverse AAGGGACTTCCTGTAACAATGCA. The expression levels were calculated based on the $2^{-\Delta \Delta C T}$ method [24].

\section{Statistical analysis}

All values are expressed as mean values \pm SD. Student's unpaired t-test was used to evaluate differences between treated groups and their respective controls. The significance of dose or time responses was assessed by repeated measures analysis. Graphic data was prepared with Sigmaplot ${ }^{\circledR}$ (Systat Software, Inc.). $\mathrm{IC}_{50}$ values were determined using the four parameter logistic curve.

\section{Results}

$\nabla$

In a pharmacological screening with CCRF-CEM leukaemia cells, a petroleum ether and a $\mathrm{MeOH}$ extract of Saussurea lappa roots were investigated by the MTS viability assay. While the petroleum ether extract exhibited strong growth reduction $(0.3 \pm 0.1 \%$ of control cells at $10 \mu \mathrm{g} / \mathrm{mL}$ ), the $\mathrm{MeOH}$ extract had no effect on the proliferation and viability of these cells (data not shown). Activity-guided fractionation of the petroleum ether extract led to the isolation of costunolide and dehydrocostus lactone ( $\bullet$ Fig. $\mathbf{1}$ ) as main and active compounds. Their structures were elucidated using ${ }^{1} \mathrm{H}$ and ${ }^{13} \mathrm{C}$ NMR experiments and by comparison with published data $[25,26]$.

To investigate the influence on cell growth, STS cell lines were exposed to $0,0.5,1.0,5.0,10.0,25.0,50.0$, and $100.0 \mu \mathrm{g} / \mathrm{mL}$ of each compound for 24,48 , and $72 \mathrm{~h}$. After these incubation periods, cells were measured by the MTS assay $(n=12)$. 0 Fig. 2 A and $\mathbf{B}$ show the $48 \mathrm{~h}$ values of the time- and dose-dependent inhibition of the cell viability. $\mathrm{IC}_{50}$ values are listed in $\mathbf{O}$ Fig. $2 \mathrm{C}$. Averaged across all cell lines (mean and SD of all obtained $\mathrm{IC}_{50}$ values), costunolide affected growth behaviour after $48 \mathrm{~h}$ by $9.7 \pm 0.1 \mu \mathrm{g} / \mathrm{mL}$ ( $\triangleq 41.7 \pm 0.4 \mu \mathrm{M}$ ), whereas the influence of dehydrocostus lactone was considerably higher by $7.3 \pm 1.1 \mu \mathrm{g} / \mathrm{mL}(\triangleq 31.7 \pm 4.8 \mu \mathrm{M})$. The commercial chemotherapeutic agents used as positive controls inhibited the growth of STS cell lines between 13.9 and $34.8 \mu \mathrm{M}$ in the case of cisplatin and 0.7 and $2.5 \mu \mathrm{M}$ in the case of doxorubicin. In control experiments, DMSO alone $(0.5 \%)$ had no influence on the cells, regardless of incubation time.

To investigate the effects of costunolide and dehydrocostus lactone on cell cycle, SW-872, SW-982, and TE-671 cells were exposed to their respective $\mathrm{IC}_{50}$ of costunolide or dehydrocostus

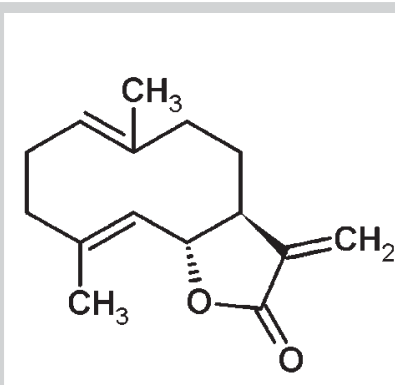

costunolide

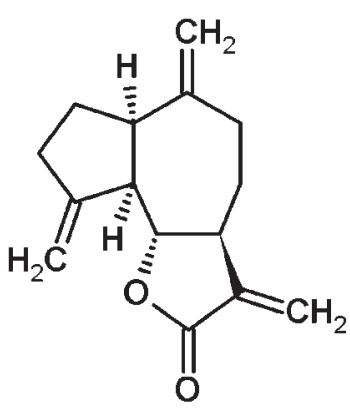

dehydrocostus lactono
Fig. 1 Structures of active compounds identified in roots of Saussurea lappa. 

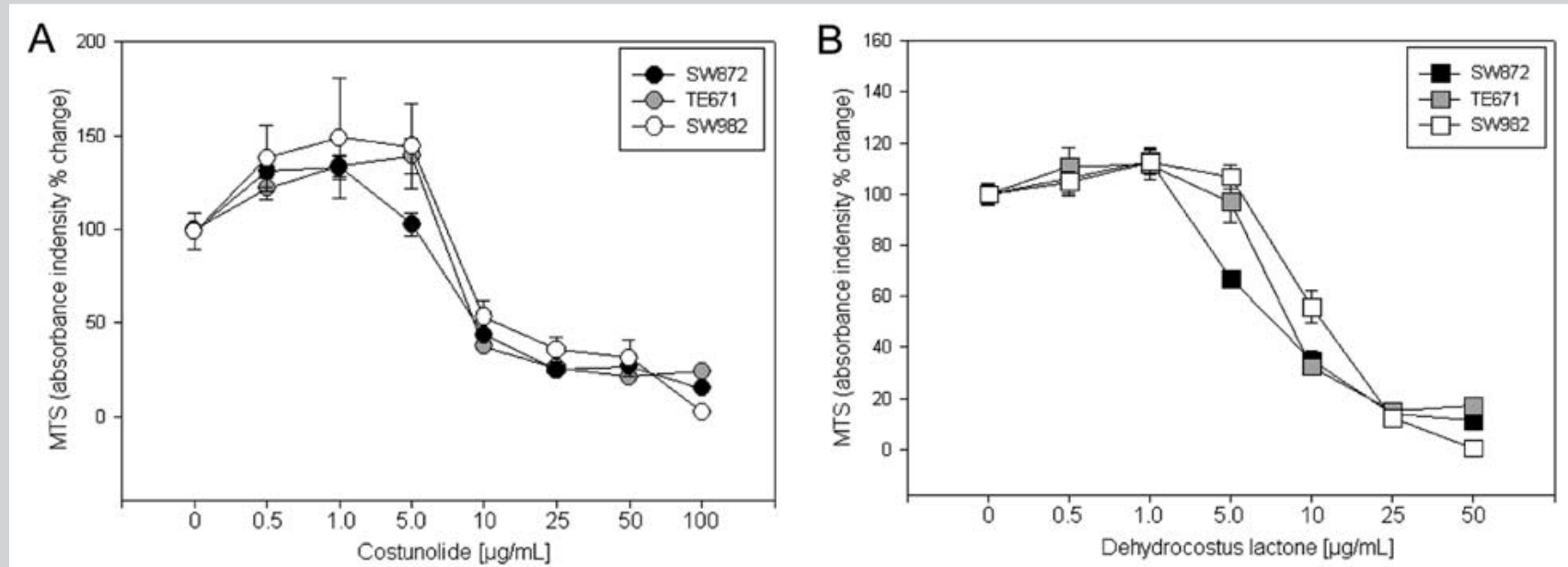

\begin{tabular}{|c|c|c|c|c|}
\hline \multicolumn{4}{|c|}{ IC $_{50}$ after $48 \mathrm{~h}$ incubation } \\
\cline { 2 - 5 } & \multicolumn{3}{|c|}{ Costunolide } & \multicolumn{2}{c|}{ Dehydrocostus lactone } \\
\hline SW-872 & $9.71 \mu \mathrm{g} / \mathrm{mL}$ & $\mathrm{SW}-872$ & $7.41 \mu \mathrm{g} / \mathrm{mL}$ \\
\hline $\mathrm{SW}-982$ & $9.61 \mu \mathrm{g} / \mathrm{mL}$ & $\mathrm{SW}-982$ & $6.17 \mu \mathrm{g} / \mathrm{mL}$ \\
\hline $\mathrm{TE}-671$ & $9.75 \mu \mathrm{g} / \mathrm{mL}$ & & $T E-671$ & $8.33 \mu \mathrm{g} / \mathrm{mL}$ \\
\hline
\end{tabular}

Fig. 2 Cell viability assay (MTS). Proliferation of SW-872, SW-982, and TE-671 cells when exposed to A $0.5-100 \mu \mathrm{g} / \mathrm{mL}$ costunolide and B $0.5-50 \mu \mathrm{g} / \mathrm{mL}$ dehydrocostus lactone for $48 \mathrm{~h}$. Viability decreased dose-dependently. Data are represented as relative absorbance intensity of untreated cells (100\%) $(n=12)$. IC 50 values of both agents are listed in $C$. lactone. Interestingly, when treated with costunolide, no significant changes in cell cycle distribution were detected compared to untreated control groups. In contrast, dehydrocostus lactone caused a decrease in the number of cells in the G1 phase after 48 and $72 \mathrm{~h}$, which was accompanied by an increase of the number of $S$ and G2/M phase cells. Measured and statistical data are summarised in $\odot$ Tables 1 and 2.

Apoptosis induction was investigated by annexin V/PI staining and quantified by measuring caspase $3 / 7$ activity and caspase- 3 cleavage. Figs. 3, $\mathbf{4}$ and $\mathbf{5}$ show the different effects of costunolide and dehydrocostus lactone regarding apoptosis. In adherent cells, the trypsinisation influences the annexin $\mathrm{V}$ staining in most cases and, therefore, the quantification due to the gating is diffi- cult. Nonetheless, SW-872, SW-982, and TE-671 cells treated with dehydrocostus lactone for $48 \mathrm{~h}$ exhibited two populations with strong annexinV/PI staining. It can be concluded that these are late apoptotic populations. Costunolide seemed to have only a small effect on apoptosis induction ( Fig. 3).

Active caspase-3, a marker for cells undergoing apoptosis, consists of a heterodimer of 17 and $12 \mathrm{kDa}$ subunits, which is derived from a $32 \mathrm{kDa}$ proenzyme [27]. Cleaved caspase-3 was measured by flow cytometry after $48 \mathrm{~h}$ exposure to the $\mathrm{IC}_{50}$ of costunolide and dehydrocostus lactone. The FACS histograms represent untreated cells (striated lines) versus costunolide-treated cells (checkered lines), and dehydrocostus lactone-treated cells (vertical stripped lines). In SW-872 cells, $16.93 \%$ cleaved caspase-3 was

Table 1 Cell cycle distribution of STS cell lines after 48 and $72 \mathrm{~h}$ exposure to costunolide $(\mathrm{n}=3, \mathrm{mean} \pm \mathrm{SD})$.

\begin{tabular}{|c|c|c|c|c|c|c|c|}
\hline Cell line & Treatment & Time & $G_{0} G_{1}(\%)$ & S (\%) & $\mathrm{G}_{2} / \mathrm{M}(\%)$ & $\mathrm{Pi}(\%)$ & SPF (\%) \\
\hline \multirow[t]{4}{*}{ TE-671 } & control & $48 \mathrm{~h}$ & $58.17 \pm 0.91$ & $25.21 \pm 0.18$ & $16.22 \pm 6.40$ & $41.83 \pm 0.01$ & $25.20 \pm 0.01$ \\
\hline & costunolide & $48 \mathrm{~h}$ & $53.52 \pm 0.41$ & $28.66 \pm 0.16$ & $18.22 \pm 0.25$ & $46.48 \pm 0.01$ & $28.26 \pm 0.00$ \\
\hline & control & $72 \mathrm{~h}$ & $86.28 \pm 0.49$ & $10.95 \pm 1.97$ & $2.77 \pm 2.46$ & $1.72 \pm 0.00$ & $10.95 \pm 0.02$ \\
\hline & costunolide & $72 \mathrm{~h}$ & $84.96 \pm 0.86$ & $12.39 \pm 1.52$ & $2.66 \pm 2.38$ & $15.04 \pm 0.01$ & $12.38 \pm 0.02$ \\
\hline \multirow[t]{4}{*}{ SW-982 } & control & $48 \mathrm{~h}$ & $75.89 \pm 0.14$ & $13.13 \pm 0.31$ & $10.98 \pm 0.17$ & $24.11 \pm 0.00$ & $13.13 \pm 0.00$ \\
\hline & costunolide & $48 \mathrm{~h}$ & $66.93 \pm 2.06$ & $15.62 \pm 0.74$ & $17.46 \pm 1.32$ & $33.07 \pm 0.20$ & $15.62 \pm 0.01$ \\
\hline & control & $72 \mathrm{~h}$ & $76.63 \pm 0.33$ & $14.83 \pm 0.45$ & $8.54 \pm 0.12$ & $23.66 \pm 0.00$ & $14.83 \pm 0.00$ \\
\hline & costunolide & $72 \mathrm{~h}$ & $81.75 \pm 0.19$ & $8.72 \pm 0.40$ & $9.54 \pm 0.20$ & $18.25 \pm 0.00$ & $8.72 \pm 0.00$ \\
\hline \multirow[t]{4}{*}{ SW-872 } & control & $48 \mathrm{~h}$ & $77.46 \pm 0.58$ & $14.14 \pm 0.01$ & $8.42 \pm 0.59$ & $22.54 \pm 0.58$ & $14.13 \pm 0.01$ \\
\hline & costunolide & $48 \mathrm{~h}$ & $75.16 \pm 0.97$ & $15.02 \pm 0.32$ & $9.83 \pm 0.65$ & $24.84 \pm 0.97$ & $15.02 \pm 0.32$ \\
\hline & control & $72 \mathrm{~h}$ & $88.60 \pm 0.24$ & $8.51 \pm 0.27$ & $8.89 \pm 0.50$ & $11.39 \pm 0.00$ & $7.53 \pm 0.00$ \\
\hline & costunolide & $72 \mathrm{~h}$ & $90.96 \pm 0.05$ & $6.15 \pm 0.11$ & $2.90 \pm 0.05$ & $9.04 \pm 0.00$ & $5.65 \pm 0.00$ \\
\hline
\end{tabular}

* $\mathrm{P}<0.05 ; \mathrm{Pi}=\left(\mathrm{S}+\mathrm{G}_{2} / \mathrm{M}\right) /\left(\mathrm{G}_{0} / \mathrm{G}_{1}+\mathrm{S}+\mathrm{G}_{2} / \mathrm{M}\right) ; \mathrm{SPF}=\mathrm{S} /\left(\mathrm{G}_{0} / \mathrm{G}_{1}+\mathrm{S}+\mathrm{G}_{2} / \mathrm{M}\right)$ 


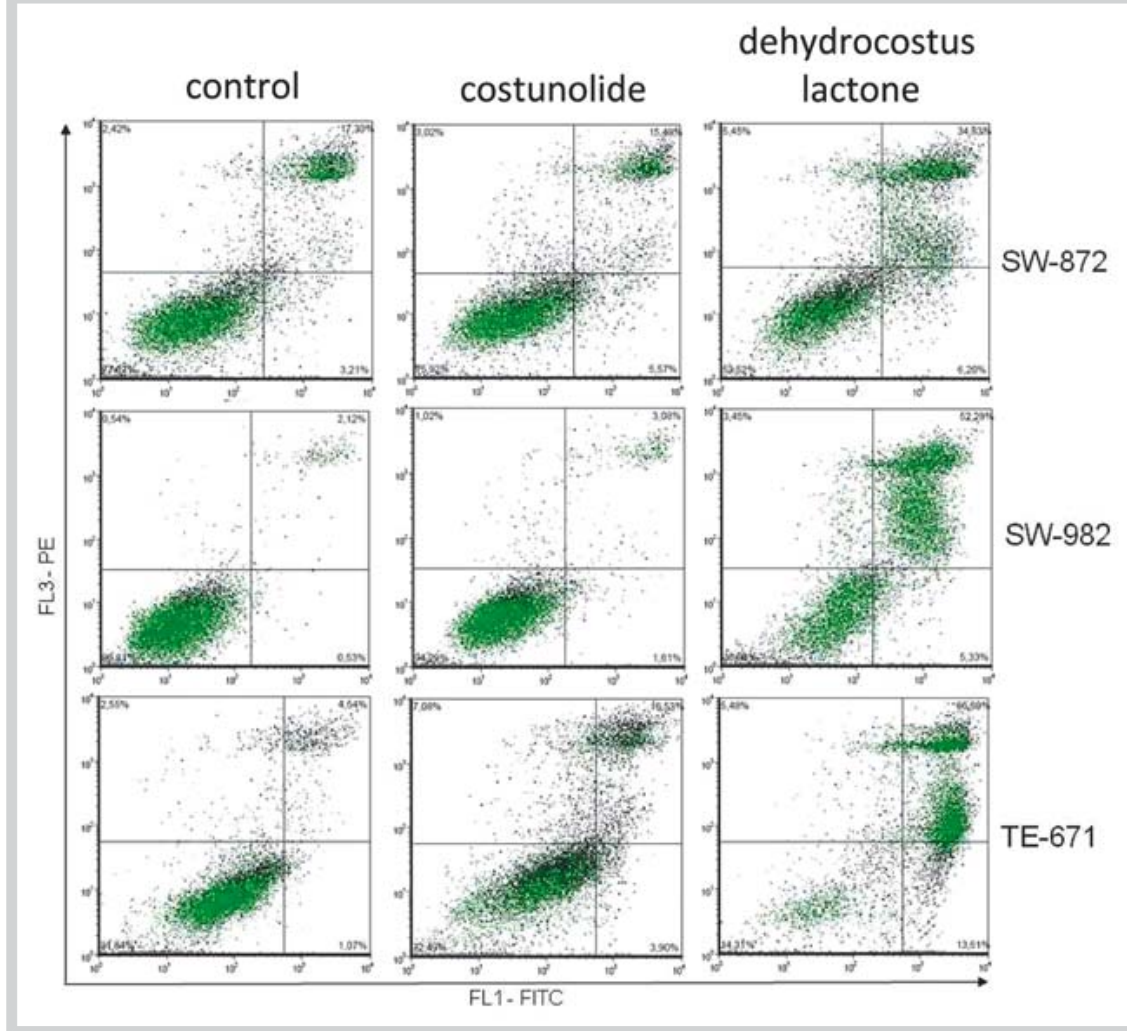

Fig. 3 Annexin V/PI apoptosis assay. SW-872, SW-982, and TE-671 cells treated with the $\mathrm{IC}_{50}$ concentration of dehydrocostus lactone for $48 \mathrm{~h}$ exhibited two populations with strong annexinV/PI staining. This indicates that these are late apoptotic populations. Treatment with the $\mathrm{IC}_{50}$ concentration of costunolide resulted in no apoptotic events.

detected in gated costunolide-treated and $96.82 \%$ in dehydrocostus lactone-treated cells ( Fig. 4A). In contrast, the SW-982 cells showed almost no cleaved caspase-3 $(10.72 \%$ and $12.93 \%$ of gated cells, respectively) ( Fig. 4B). Also the dehydrocostus lactone-treated TE-671 cells showed a significantly higher proportion of cleaved caspase-3 $(91.74 \%)$ in contrast to costunolidetreated cells (35.51\%) ( Fig. 4C). In addition, caspase 3/7 activity was measured by the Caspase-Glo ${ }^{\circledR} 3 / 7$ assay in SW-872 ( Fig. 5A), SW-982 ( Fig. 5B), and TE-671 cells ( Fig. 5C). It peaked after 24 and $48 \mathrm{~h}$ in SW-872 and TE-671 cells. Furthermore, the apoptotic induction by dehydrocostus lactone was confirmed by PARP cleavage in TE-671 cells ( Fig. 5D).

Finally, we investigated the effects of costunolide and dehydrocostus lactone on mRNA expression levels of $A B C$ transporters using real-time RT-PCR. Three major drug transporters (ABCB1/
MDR1, ABCC1/MRP1, and ABCG2/BCRP1) were analysed. Costunolide did not significantly change the ABCB1/MDR1 expression. The expression levels of ABCC1/MRP1 and ABCG2/BCRP1 were significantly upregulated in costunolide-treated SW-872 and SW-982 cells ( Fig. 6A). Dehydrocostus lactone treatment influenced the expression level of ABCB1/MDR1 and ABCG2/BCRP1 significantly in SW-872 and SW-982 cells, but not in the TE-671 cells. The ABCB1/MDR1 level was significantly downregulated in dehydrocostus lactone-treated SW-872 ( $\mathrm{p}=0.0068)$ and SW-982 cells $(p=0.0024)$. Dehydrocostus lactone also significantly lowered the expression levels of ABCG2/BCRP1 in the SW-872 $(p=0.0058)$ and SW-982 cells $(p=0.0081)$ ( Fig. 6B). Furthermore, the ABCC1/MRP1 expression was downregulated in TE671 cells $(p=0.0014)$, but not in the other cells lines. The downregulation of the $A B C G 2 / B C R P 1$ and $A B C B 1 / M D R 1$ transporter

Table 2 Cell cycle distribution of STS cell lines after 48 and $72 \mathrm{~h}$ exposure to dehydrocostus lactone $(n=3$, mean \pm SD).

\begin{tabular}{|c|c|c|c|c|c|c|c|}
\hline Cell line & Treatment & Time & $G_{0} G_{1}(\%)$ & S (\%) & $\mathrm{G}_{2} / \mathrm{M}(\%)$ & $\mathrm{Pi}(\%)$ & SPF (\%) \\
\hline \multirow[t]{4}{*}{ TE-671 } & control & $48 \mathrm{~h}$ & $39.71 \pm 0.48$ & $42.24 \pm 0.09$ & $18.06 \pm 0.40$ & $60.30 \pm 0.01$ & $42.23 \pm 0.00$ \\
\hline & dehydrocostus lactone & $48 \mathrm{~h}$ & $27.69 \pm 1.89$ & $43.20 \pm 0.42$ & $29.12 \pm 2.31$ & $72.31 \pm 0.02$ & $43.20 \pm 0.00$ \\
\hline & control & $72 \mathrm{~h}$ & $76.99 \pm 0.56^{*}$ & $14.14 \pm 0.69^{*}$ & $8.87 \pm 0.13^{*}$ & $23.00 \pm 0.01$ & $14.13 \pm 0.01$ \\
\hline & dehydrocostus lactone & $72 \mathrm{~h}$ & $56.26 \pm 0.74^{*}$ & $28.36 \pm 0.35^{*}$ & $15.38 \pm 0.38^{*}$ & $43.74 \pm 0.01$ & $28.36 \pm 0.00$ \\
\hline \multirow[t]{4}{*}{ SW-982 } & control & $48 \mathrm{~h}$ & $79.24 \pm 1.65^{*}$ & $11.07 \pm 0.48^{*}$ & $9.69 \pm 1.16^{*}$ & $20.76 \pm 0.02$ & $11.07 \pm 0.00$ \\
\hline & dehydrocostus lactone & $48 \mathrm{~h}$ & $52.96 \pm 0.44^{*}$ & $21.17 \pm 1.11^{*}$ & $25.88 \pm 1.55^{*}$ & $47.04 \pm 0.00$ & $21.16 \pm 0.01$ \\
\hline & control & $72 \mathrm{~h}$ & $80.80 \pm 0.79 *$ & $11.31 \pm 0.37^{*}$ & $7.90 \pm 1.17^{*}$ & $19.20 \pm 0.01$ & $11.31 \pm 0.00$ \\
\hline & dehydrocostus lactone & $72 \mathrm{~h}$ & $55.71 \pm 1.70^{*}$ & $19.13 \pm 0.15^{*}$ & $25.17 \pm 1.84^{*}$ & $44.29 \pm 0.02$ & $19.12 \pm 0.00$ \\
\hline \multirow[t]{4}{*}{ SW-872 } & control & $48 \mathrm{~h}$ & $81.91 \pm 0.32 *$ & $12.56 \pm 0.18^{*}$ & $5.51 \pm 0.50^{*}$ & $18.08 \pm 0.00$ & $12.58 \pm 0.00$ \\
\hline & dehydrocostus lactone & $48 \mathrm{~h}$ & $67.30 \pm 0.00^{*}$ & $18.74 \pm 0.80^{*}$ & $14.04 \pm 0.80^{*}$ & $32.77 \pm 0.00$ & $18.74 \pm 0.00$ \\
\hline & control & $72 \mathrm{~h}$ & $91.09 \pm 0.69 *$ & $6.84 \pm 0.52^{*}$ & $2.08 \pm 0.18^{*}$ & $8.91 \pm 0.01$ & $6.83 \pm 0.01$ \\
\hline & dehydrocostus lactone & $72 \mathrm{~h}$ & $50.81 \pm 0.83^{*}$ & $33.25 \pm 0.95^{*}$ & $15.95 \pm 1.77^{*}$ & $49.20 \pm 0.01$ & $33.25 \pm 0.01$ \\
\hline
\end{tabular}

* $\mathrm{P}<0.05 ; \mathrm{Pi}=\left(\mathrm{S}+\mathrm{G}_{2} / \mathrm{M}\right) /\left(\mathrm{G}_{0} / \mathrm{G}_{1}+\mathrm{S}+\mathrm{G}_{2} / \mathrm{M}\right) ; \mathrm{SPF}=\mathrm{S} /\left(\mathrm{G}_{0} / \mathrm{G}_{1}+\mathrm{S}+\mathrm{G}_{2} / \mathrm{M}\right)$ 


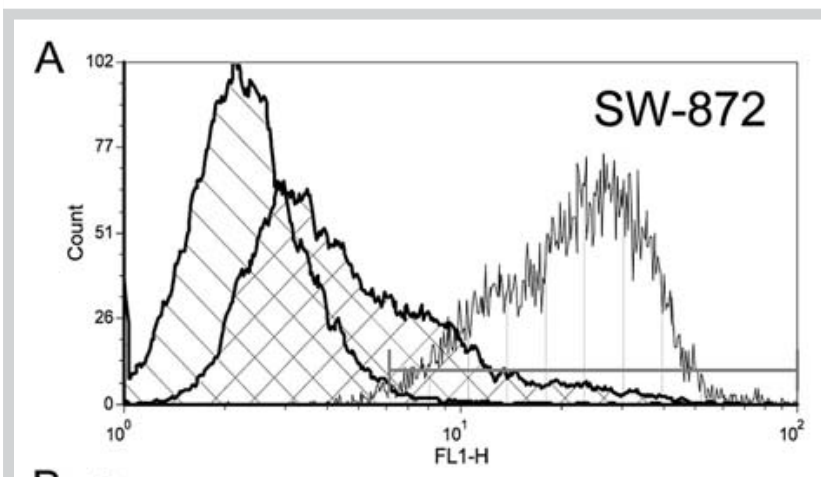

B

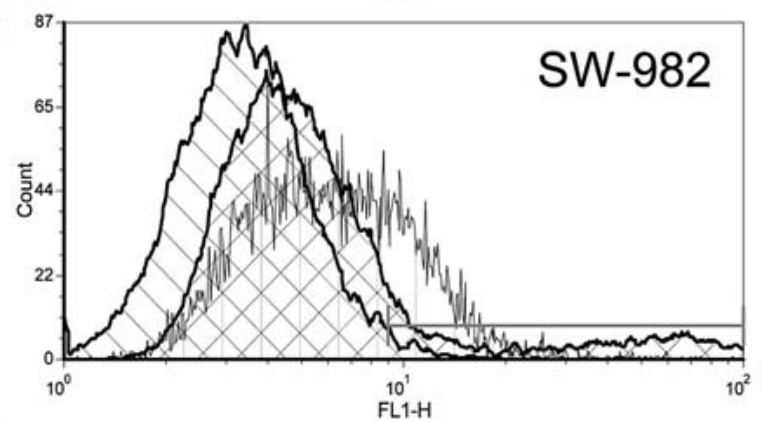

C

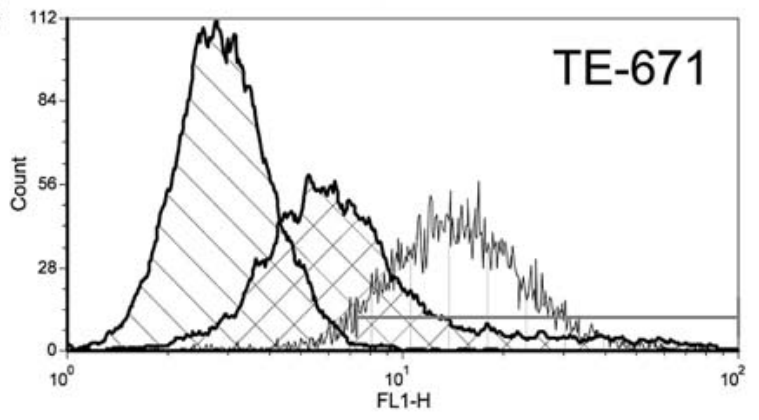

Fig. 4 Cleaved caspase-3 apoptosis assay. A SW-872, B SW-982, and C TE-671 cells were treated with the IC 50 concentrations of costunolide or dehydrocostus lactone for $48 \mathrm{~h}$. Cleavage of caspase- 3 was detected by flow cytometry. The $y$-axis denotes cell counts, and the $x$-axis represents fluorescence intensity of FITC antibody. Striated lines represent untreated control cells, checkered lines represent costunolide treated cells, and vertical stripped lines represent dehydrocostus lactone-treated cells. Caspase-3 cleavage indicative for apoptotic cell death was especially found in SW-872 and TE-671 cells when exposed to dehydrocostus lactone.

expression in dehydrocostus lactone-treated SW-872 and SW982 cells was confirmed using Western blot analysis ( $\bullet$ Fig. 7).

\section{Discussion}

$\nabla$

Saussurea lappa Clarke is a well-known plant in Asia, where it is used in herbal medicine $[17,18]$. Previous in vitro and in vivo studies have shown that extracts of this plant have antiulcerative [28], anti-inflammatory [29], and antitumour properties [16,18, 30]. It has been shown that sesquiterpene lactones are the major components of the roots and exhibit various biological activities [20-22]. However, the effects of costunolide and dehydrocostus lactone in STS cells and their mechanisms of action are unknown and have yet to be analysed. Since chemotherapeutic agents in STS have been shown to be of limited efficacy, novel treatment strategies and therapeutic applications are needed and must be tested. In the present study, we have investigated the effects of costunolide and dehydrocostus lactone on cell viability, cell cycle, apoptosis, and $A B C$ transporter expression levels in different human STS cell lines.

The inhibition of cell proliferation by such extracts and isolated compounds have already been shown in other cell types $[18,31$, 32] and suppressed telomerase activity and dehydrocostus lactone-induced apoptosis have been reported in some human cancer cell lines [33-38]. Our in vitro study has shown that costunolide and dehydrocostus lactone inhibited the growth of human STS cell lines dose- and time-dependently. $\mathrm{IC}_{50}$ values ranged from $41.3 \mu \mathrm{M}$ to $42.0 \mu \mathrm{M}$ in the case of costunolide, and from 26.8 to $36.1 \mu \mathrm{M}$ in the case of dehydrocostus lactone. Furthermore, we analysed the influence on cell cycle distribution. Treatment with costunolide did not alter the cell cycle distribution after 48 and $72 \mathrm{~h}$. In contrast, dehydrocostus lactone caused a significant decrease of cells in the G1 phase and an increase at $S$ and G2/M phases. It has also been shown that Saussurea lappa extracts induce G2 growth arrest and apoptosis in gastric cancer cells [31,32]. Furthermore, an effect of dehydrocostus lactone on cell cycle distribution was reported in MDA-MB-231 breast and SK-OV-3 ovarian cancer cells [42,43]. Both types of cancer cells were also arrested at the G2/M interface. Cells can be temporarily arrested to allow for cellular damage to be repaired, or the arrest may result in the activation of pathways leading to programmed cell death $[44,45]$. We detected not only the G2/M arrest but also morphological changes indicative for apoptosis such as detached cells, membrane blebbing, and rounded morphology. Additional annexin $V$ staining also showed a clear hint of apoptosis. Annexin V-FITC is used to quantitatively determine the percentage of cells within a population that are undergoing apoptosis. It relies on the property of cells to lose membrane asymmetry in the early phases of apoptosis. Propidium iodide is a standard flow cytometric viability probe and used to distinguish viable from nonviable cells. We found significant late apoptotic populations in dehydrocostus lactone-treated STS cells, with TE-671 showing the strongest effect. To substantiate the apoptotic effect, caspase 3/7 activity was measured and could be confirmed by FACS caspase- 3 measurements. Activation of caspases by dehydrocostus lactone, especially those involved in the intrinsic apoptotic pathway, have also been reported for other types of cancer cells [36,39-41] but not yet for STS cells.

Some plant extracts of Chinese herbs were found to inhibit MDR efflux pumps [46], which mediate multidrug resistance in many types of cancer. Therefore, we analysed the mRNA expression of major drug transporters (ABCB1/MDR1, ABCC1/MRP1, and ABCG2/BCRP1) of the ABC transporter family, which may provide highly suitable targets for clinical cancer therapy. ABCB1/MDR1 and ABCG2/BCRP1 were significantly downregulated in SW-872 and SW-982 cell lines after treatment with dehydrocostus lactone indicating that this compound has a certain potential to circumvent multidrug resistance in these cells.

In summary, we have shown that costunolide and dehydrocostus lactone inhibited the growth of STS cells in vitro. Our data indicate that particularly dehydrocostus lactone is a potential therapeutic lead for the development of novel STS treatment strategies. So far, it seems to induce caspase-dependent apoptosis and may circumvent cancer drug resistance by reducing the expression of $A B C$ transporters. Our findings provide the basis for further investigations to clarify novel treatment regimens for drug-resistant tumours. 

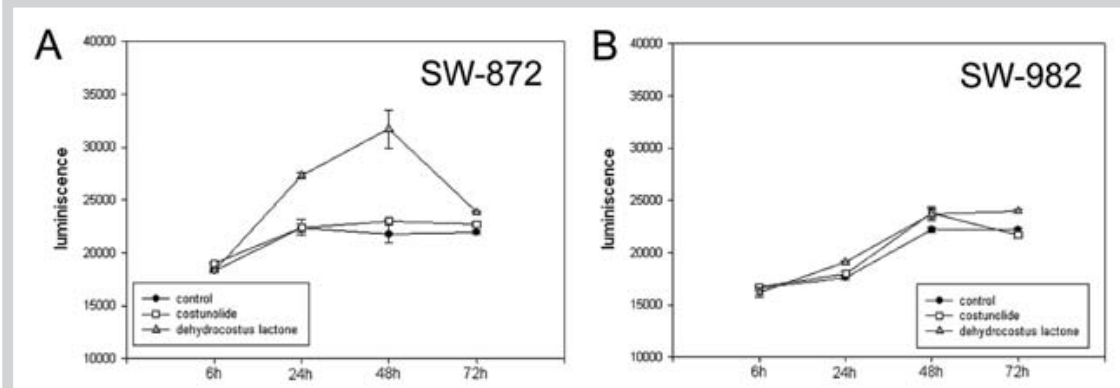

Fig. 5 Caspase-Glo ${ }^{\circledR} 3 / 7$ apoptosis assay. The activity of caspase- $3 / 7$ was measured in A SW-872, B SW-982, and C TE-671 cells by the Caspase-Glo ${ }^{\circledR}$ 3/7 assay. Dehydrocostus lactone-treated SW-872 and TE-671 cells showed a significantly higher level of cleaved caspase- 3 and active caspase-3/7 compared to costunolide-treated cells. D Whole cell lysates of cells exposed to dehydrocostus lactone were subjected to Western blot analysis using antiPARP antibody. The results confirmed the supposed apoptosis induction.

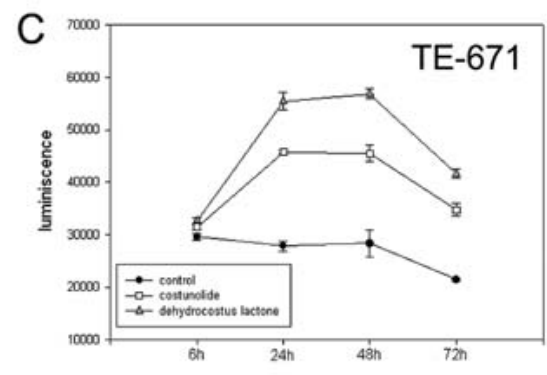

D

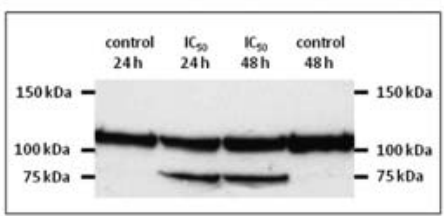

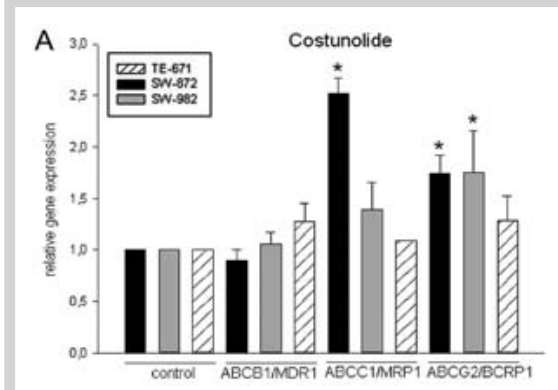

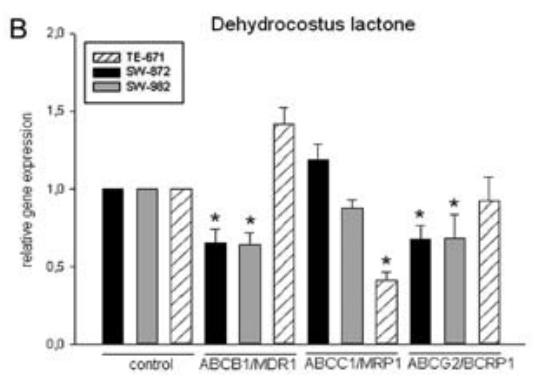

Fig. 6 Relative mRNA expression of ABC transporter genes measured by real-time RT-PCR. Expression levels of $A B C B 1 / M D R 1, A B C C 1 / M R P 1$, and $A B C G 2 / B C R P 1$ are shown in untreated (control), A costunolide-, and $\mathbf{B}$ dehydrocostus lactone-treated STS cell lines $(n=8)$. The expression levels were normalised $(\Delta C \mathrm{t})$ to the expression of $\beta$-actin, GAPDH, and hprt-n as an internal control and compared to the corresponding $\Delta \mathrm{Ct}(\Delta \Delta \mathrm{Ct})$ of control cells. ${ }^{*} \mathrm{P}<0.05$.

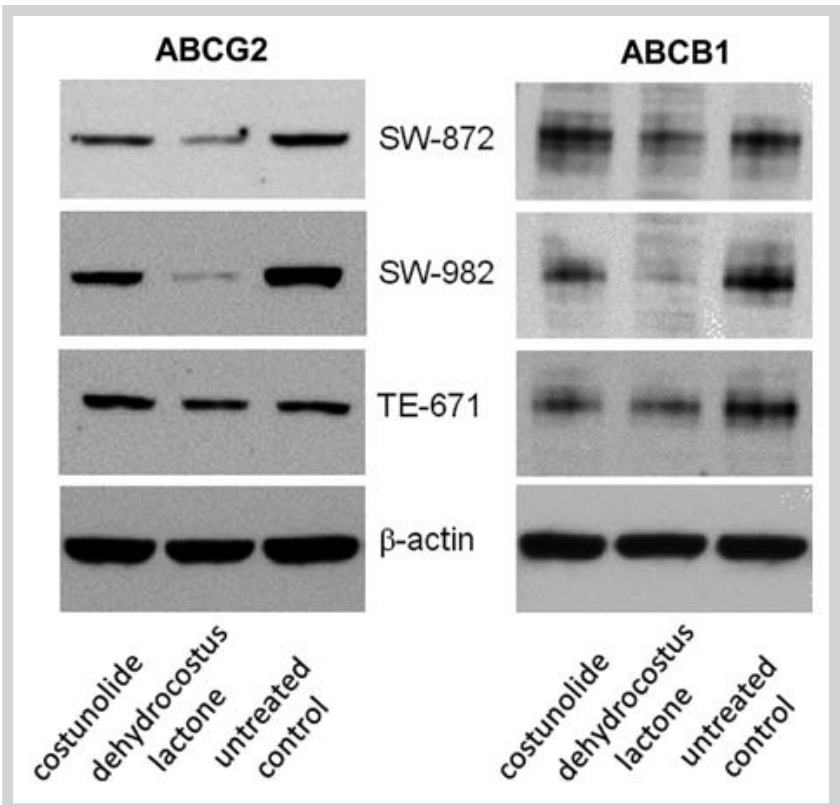

Fig. 7 Western blot analysis of $A B C$ transporter genes. The total protein analysis confirmed the downregulation of the ABCG2/BCRP1 and ABCB1/ MDR1 transporters in dehydrocostus lactone-treated SW-872 and SW-982 cells.

\section{Acknowledgements}

$\nabla$

Financial support from the Medical University of Graz and the Austrian Science Fund (FWF, P21114) is gratefully acknowledged. Furthermore, we thank Prof. Dr. Thomas Efferth, Institute of Pharmacy, University of Mainz, Germany, for providing the CCRF-CEM leukaemia cell line and Prof. Dr. X.-J. Hao, Kunming Institute of Botany, Chinese Academy of Sciences, Kunming, China, for plant identification.

\section{Conflict of Interest}

$\nabla$

There are no conflicts of interest.

\section{Affiliations}

${ }^{1}$ Institute of Pharmaceutical Sciences, Department of Pharmacognosy,

Karl-Franzens-University, Graz, Austria

2 Center for Medical Research, Medical University of Graz, Graz, Austria

${ }^{3}$ Department of Orthopaedic Surgery, Medical University of Graz, Graz,

Austria

${ }^{4}$ Institute of Pharmaceutical Sciences, Department of Pharmaceutical

Chemistry, Karl-Franzens-University, Graz, Austria

${ }^{5}$ Department of Plant Materials Sciences and Utilisation, Joanneum Research Forschungsgesellschaft mbH, Graz, Austria 


\section{References}

1 Chugh R, Dunn R, Zalupski M, Biermann JS, Sondak VK, Mace JR. Phase II study of 9-nitro-camptothecin in patients with advanced chordoma or soft tissue sarcoma. J Clin Oncol 2005; 23: 3597-3604

2 Olstad OK, Gautvik VT, Reppe S, Rian E, Jemtland R, Ohlsson C. Molecular heterogeneity in human osteosarcoma demonstrated by enriched mRNAs isolated by directional tag PCR substraction cloning. Anticancer Res 2003; 23: 2201-2216

3 Sessa C, Perotti A, Noberasco C, De Braud F, Gallerani E, Cresta S. Phase 1 clinical and pharmacokinetic study of trabectedin and doxorubicin in advanced soft tissue sarcoma and breast cancer. Eur J Cancer 2009; 45: 1153-1161

4 Antman KH, Crowley J, Balcerzak SP, Rivkin SE, Weiss GR, Elias A. An intergroup phase III randomized study of doxorubicin and dacarbazine with or without ifosfamide and masna in advanced soft tissue and bone sarcomas. J Clin Oncol 1993; 11: 1276-1285

5 Antman KH. Adjuvant therapy of sarcomas of soft tissue. Semin Oncol 1997; 24: 556-560

6 Borden EC, Amato DA, Edmonson JH, Ritch PS, Shiraki M. Randomized comparison of doxorubicin and vindesine to doxorubicin for patients with metastatic soft tissue sarcomas. Cancer 1990; 66: 862-867

7 Greenall MJ, Magill GB, Decosse JJ, Brennan MF. Chemotherapy for soft tissue sarcoma. Surg Gynecol Obstet 1986; 62: 193-198

8 Kuwano M, Toh S, Uchiumi T, Takano H, Kohno K, Wada M. Multidrug resistance-associated protein subfamily transporters and drug resistance. Anticancer Drug Des 1999; 14: 123

9 Allen JD, Brinkhuis RF, Wijnholds J, Schinkel AH. The mouse Bcrp1/Mxr/ Abcp gene: amplification and overexpression in cell lines selected for resistance to ropotecan, mitoxantrone, or doxorubicin. Cancer Res 1999; 59: 4237-4241

10 Litman T, Druley TE, Stein WD, Bates SE. From MDR to MXR: new understanding of multidrug resistance systems, their properties and clinical significance. Cell Mol Life Sci 2001; 58: 931-959

11 Fletcher JI, Haber M, Henderson MJ, Norris MD. ABC transporters in cancer: more than just drug efflux pumps. Nat Rev Cancer 2010; 10: 147156

12 Oda Y, Saito T, Tateishi N, Ohishi Y, Tamiya S, Yamamoto H, Yokoyama R, Uchiumi T, Iwamoto Y, Kuwano M, Tsuneyoshi M. ATP-binding cassette superfamily transporter gene expression in human soft tissue sarcomas. Int J Cancer 2005; 114: 854-862

13 Ebert B, Seidel A, Lampen A. Identification of BCRP as transporter of ebnzol[a]-pyrene conjugates metabolically formed in Caco-2 cells and its induction by Ah-receptor agonists. Carcinogenesis 2005; 26: 754763

$14 \mathrm{Wu} C \mathrm{CP}$, Hsieh $\mathrm{CH}, \mathrm{Wu}$ YS. The emergence of drug transporter-mediated multidrug resistance to cancer chemotherapy. Mol Pharm 2011; 8: 1996-2011

15 Newman DJ, Cragg GM. Natural products as source of new drugs over the last 25 years. J Nat Prod 2007; 70: 461-477

16 Efferth T, Kahl S, Paulus K, Adams M, Rauh R, Boechzelt H, Bauer R. Phytochemistry and pharmacogenomics of natural products derived from traditional Chinese medicine and Chinese materia medica with activity against tumor cells. Mol Cancer Ther 2008; 7: 152-161

17 Duke JA, Ayensu S. Medicinal plants of China, Vol. 1. Michigan: Reference Publications Inc.; 1985: 178

18 Pandey MM, Rastogi S, Rawat AK. Saussurea costus: botanical, chemical and pharmacological review of an ayurvedic medicinal plant. J Ethnopharmacol 2007; 110: 379-390

19 Choi JY, Na M, Hyun Hwang I, Ho Lee S, Young Bae E, Yeon Kim B. Isolation of betulinic acid, its methyl ester and guaiane sesquiterpenoids with protein tyrosine phosphatase $1 \mathrm{~B}$ inhibitory activity from the roots of Saussurea lappa C.B.Clarke. Molecules 2009; 14: 266-272

20 Duan JA, Hou P, Tang Y, Liu P, Su S, Liu H. A new sesquiterpene and other constituents from Saussurea lappa root. Nat Prod Commun 2010; 5: $1531-1534$

21 Paul A, Bawdekar AS, Joshi RS, Somashekara Rao K, Kelkar GR, Battacharya SC. Terpenoids XX: examination of costus root oil. Perfume Essential Oil Rec 1960; 15: 115-120

22 Robles M, Aregullin M, West J, Rodriguez E. Recent studies on the zoopharmacognosy, pharmacology and neurotoxicology of sesquiterpene lactones. Planta Med 1995; 61: 199-203

23 Scudiero DA, Shoemaker RH, Paull KD, Monks A, Tierney S, Nofziger TH. Evaluation of a soluble tetrazolium/formazan assay for cell growth and drug sensitivity in culture using human and other tumor cell lines. Cancer Res 1988; 48: 4827-4833

24 Vandesompele J, De Preter K, Pattyn F, Poppe B, Van Roy N, De Paepe A. Accurate normalization of real-time quantitative RT-PCR data by geometric averaging of multiple internal control genes. Genome Biol 2002; 3: research 0034.1-11

25 Jacobsson U, Kumar V, Saminathan S. Sesquiterpene lactones from $\mathrm{Mi}$ chelia champaca. Phytochemistry 1994; 39: 839-843

26 Yuuya S, Hagiwara H, Suzuki T, Ando M, Yamada A, Suda K. Guaianolides as immunomodulators. Synthesis and biological activities of dehydrocostus lactone, mokko lactone, eremanthin, and their derivatives. J Nat Prod 1999; 62: 22-30

27 Taylor RC, Cullen SP, Martin SJ. Apoptosis: controlled demolition at the cellular level. Mol Cell Biol 2008; 9: 231-241

28 Yoshikawa M, Hatakeyama S, Inoue Y, Yamahara J. Saussureamines A, B, $C, D$ and E, new anti-ulcer principles from Chinese Saussurea radix. Chem Pharm Bull (Tokyo) 1993; 41: 214-216

29 Cho JK, Baik KU, Jung JH, Park MH. In vitro anti-inflammatory effects of cynaropicrin, a sesquiterpene lactone, from Saussurea lappa. Eur J Pharmacol 2000; 398: 399-407

30 Sun CM, Syu WJ, Don MJ, Lu JJ, Lee GH. Cytotoxic sesquiterpene lactones from the root of Saussurea lappa. J Nat Prod 2003; 66: 1175-1180

31 Ko SG, Koh SH, Jun CY, Nam CG, Bae SH, Shin MK. Induction of apoptosis by Saussurea lappa and Pharbitis nil on AGS gastric cancer cells. Biol Pharm Bull 2004; 27: 1604-1610

32 Ko SG, Kim HP, Jin DH, Bae SH, Kim SH, Park CH. Saussurea lappa induces G2-growth arrest and apoptosis in AGS gastric cancer cells. Cancer Lett 2005; 220: 11-19

33 Lee MG, Lee KT, Chi SG, Park JH. Costunolide induces apoptosis by ROSmediated mitochondrial permeability transition and cytochrome $\mathrm{c}$ release. Biol Pharm Bull 2001; 24: 303-306

34 Park HJ, Kwon SH, Han YN, Choi JW, Miyamoto K, Lee SH, Lee KT. Apoptosis-inducing costunolide and a novel acyclic monoterpene from the stem bark of Magnolia sieboldii. Arch Pharm Res 2001; 24: 342-348

35 Choi JH, Lee KT. Costunolide-induced apoptosis in human leukemia cells: involvement of c-Jun N-terminal kinase activation. Biol Pharm Bull 2009; 32: 1803-1808

36 Hung JY, Hsu YL, Ni WC, Tsai YM, Yang CJ, Kuo PL, Huang MS. Oxidative and endoplasmic reticulum stress signaling are involved in dehydrocostuslactone-mediated apoptosis in human non-small cell lung cancer cells. Lung Cancer 2010; 68: 355-365

37 Choi SH, Im E, Kang HK, Lee JH, Kwak HS, Bae YT, Park HJ, Kim ND. Inhibitory effects of costunolide on the telomerase activity in human breast carcinoma cells. Cancer Lett 2005; 227: 153-162

38 Kanno S, Kitajima Y, Kakuta M, Osanai Y, Kurauchi K, Ujibe M, Ishikawa M. Costunolide-induced apoptosis is caused by receptor-mediated pathway and inhibition of telomerase activity in NALM-6 cells. Biol Pharm Bull 2008; 31: 1024-1028

39 Oh GS, Pae HO, Chung HT, Kwon JW, Lee JH, Kwon TO, Kwon SY, Chon BH, Yun YG. Dehydrocostus lactone enhances tumor necrosis factor-alphainduced apoptosis of human leukemia HL-60 cells. Immunopharmacol Immunotoxicol 2004; 26: 163-175

40 Kim EJ, Lim SS, Park SY, Shin HK, Kim JS, Park JH. Apoptosis of DU145 prostate cancer cells induced by dehydrocostus lactone isolated from the root of Saussurea lappa. Food Chem Toxicol 2008; 46: 3651-3658

$41 \mathrm{Hsu} Y \mathrm{~L}, \mathrm{Wu}$ LY, Kuo PL. Dehydrocostuslactone, a medicinal plant-derived sesquiterpene lactone, induces apoptosis coupled to endoplasmic reticulum stress in liver cancer cells. J Pharmacol Exp Ther 2009; 329: 808-819

42 Kuo PL, Ni WC, Tsai EM, Hsu YL. Dehydrocostuslactone disrupts signal transducers and activators of transcription 3 through up-regulation of suppressor of cytokine signaling in breast cancer cells. Mol Cancer Ther 2009; 8: 1328-1339

43 Choi EJ, Ahn WS. Antiproliferative effects of dehydrocostuslactone through cell cycle arrest and apoptosis in human ovarian cancer SK-OV-3 cells. Int J Mol Med 2009; 23: 211-216

44 Ziegler U, Groscurth P. Morphological features of cell death. News Physiol Sci 2004; 19: 124-128

45 Pietenpol JA, Stewart ZA. Cell cycle checkpoint signaling: cell cycle arrest versus apoptosis. Toxicology 2002; 181: 475-481

46 Molnár J, Engi H, Hohmann J, Molnár P, Deli J, Wesolowska O. Reversal of multidrug resistance by natural substances from plants. Curr Top Med Chem 2010; 10: 1757-1768 